\title{
Responses of public towards shoddy industry at Panipat
}

\author{
SUMAN PANT AND NEETA NAGPAL
}

Received: 10.01.2016; Revised: 25.04.2016; Accepted: 07.05.2016

See end of the paper for authors' affiliations SUMAN PANT

Department of Clothing and Textiles, Banasthali Vidyapeeth, BANASTHALI (RAJASTHAN) INDIA
DABSTRACT : Shoddy industry at Panipat is a popular term used for recycling of rags through yarn-making. These rags are imported from western society as they change their wardrobes more frequently as compared to Indian society. The strength of these rags being higher than rags available in India, these are preferred by industrialists. A survey was done in Panipat by the investigator through a questionnaire, circulated among people living in Panipat in three different categories of academic standards that is, under matriculation, graduates and beyond graduation, as null hypothesis that "there was no significant difference between academic standards and responses towards various attributes of the industry" were tested through statistical tests. The results for the same have been analyzed and synthesized through empirical observations and statistical techniques.

KEY WORDS: Shoddy, Attributes, Employability, Eco-friendly

- HOW TO CITE THIS PAPER : Pant, Suman and Nagpal, Neeta (2016). Responses of public towards shoddy industry at Panipat. Asian J. Home Sci., 11 (1) : 117-123, DOI: 10.15740/HAS/AJHS/11.1/117123. 